\title{
Identifikasi Molekuler Kapang Asosiasi Spons menggunakan Metode DNA Barcoding
}

\author{
Stefanie Jessica Henny Larasati, Agus Sabdono, Mada Triandala Sibero* \\ Departemen IImu Kelautan, Fakultas Perikanan dan IImu Kelautan, Universitas Diponegoro \\ JI. Prof. H. Soedarto S.H, Tembalang, Semarang, Jawa Tengah 50275 Indonesia \\ ${ }^{*}$ Corresponding author, e-mail : madatriandalasibero@lecturer.undip.ac.id
}

\begin{abstract}
ABSTRAK: Spons merupakan organisme yang memiliki pori-pori dan termasuk kedalam filum Porifera. Hewan ini merupakan filter feeders dimana spons menyaring makanannya masuk kedalam rongga tubuhnya, sehingga spons dapan memakan partikel organik seperti algae, dan mikroba, termasuk kapang. Kapang merupakan mikroorganisme eukariotik dari kingdom fungi, multiseluler, menghasilkan miselium tanpa pembentukan badan buah. Kapang dapat berfungsi sebagai penjaga keseimbangan ekosistem di perairan. Tujuan dari penelitian ini adalah mengidentifikasi dua isolat kapang yang telah diisolasi dari inang spons di ekosistem mangrove dengan menggunakan DNA barcoding. Metode dalam penelitian ini yaitu peremajaan isolat, karakterisasi morfologi yaitu warna koloni, tekstur, reverse, exudates, sclerotia, bentuk konidia, konidiofor, spora, dan septa. Identifikasi molekuler dari ekstraksi DNA, amplifikasi, elektroforesis, visualisasi DNA, sekuensing dan BLAST. Optimasi suhu annealing dilakukan pada amplifikasi DNA. Berdasarkan identifikasi molekuler dengan menggunakan primer universal (ITS1 dan ITS4) dan persamaan homologi, isolat MKMS 2.1 merupakan Trichoderma reesei (100\%) dan PKMS 2.2 merupakan spesies Fusarium solani $(99,81 \%)$.
\end{abstract}

Kata kunci: DNA Barcoding; Kapang; PCR; Spons

\section{Molecular Identification of Sponge-associated Fungi using DNA Barcoding Methods}

ABSTRACT: Sponge is an organism that has pores and belongs to the Porifera phylum. This animal is a filter feeder where the sponge filters its food into the body cavity, so the sponge can eat organic algae particles, and microbes, including mold. Mold is a eukaryotic microorganism from Fungi kingdom, multicellular, that forms mycelium without fruiting body formation. Mold has an important role in balancing the environmental quality in an ecosystem. The purpose of this study was to identify two molds that had been isolated from sponge in the mangrove ecosystem using DNA barcoding. The methods in this research were isolation refreshment, morphological characterization which were consisted of colony color, texture, reverse, exudates, sclerotia, conidia, conidiophores, spores, and septa. Molecular identification consisted of DNA extraction, amplification, electrophoresis, DNA visualization, sequences and BLAST. Annealing temperature optimization is carried out on DNA amplification. Based on molecular identification using universal primers (ITS1 and ITS4) and homological equations, MKMS 2.1 isolates were identified as Trichoderma reesei (100\%) and PKMS 2.2 were identified as Fusarium solani (99.81\%).

Keywords: DNA Barcoding; Fungi; PCR; Sponge

\section{PENDAHULUAN}

Spons merupakan salah satu invertebrata laut filum Porifera yang memiliki rongga dan struktur tubuhnya masih sangat sederhana. Spons hidup di lingkungan pesisir dan laut dalam. Spons merupakan salah satu invertebrata yang diketahui memiliki peran penting dalam siklus nitrogen, silika, dan karbon; pembentuk ekosistem terumbu karang; pengkonversi dissolved organic matter (DOM) menjadi particulate organic matter (POM); hingga menjadi bioeroders (Bell, 2008; FAO, 2017). Spons merupakan hewan sessile karena sebagian besar spons hidup menetap pada substrat, bersifat filter feeder, dan diketahui menghasilkan berbagai chemical substances sebagai 
bentuk pertahanan diri dari predator (Burns et al., 2003). Bentuk pertahanan diri dari predator juga dapat melalui mikroba simbion yang menetap pada tubuh spons (Thoms et al., 2007). Mikroba yang berasosiasi dengan inangnya memiliki fungsi ekologis yang dapat berkontribusi untuk kelangsungan hidup mikroba itu sendiri maupun untuk inangnya. Oleh karena itu perlu diketahui keanekaragaman kapang yang berasosiasi dengan spons.

Kapang merupakan mikroorganisme multiseluler berfilamen dan membentuk miselium (Miranti et al., 2015). Kapang berasal dari kingdom fungi yang tidak membentuk badan buah, berukuran mikrosopis, dan bersifat heterotrof karena kapang memperoleh makanan dengan cara menyerap nutrisi dari inang asosiasinya (Richards et al., 2012). Mikroorganisme ini mempunyai peran penting di perairan. Kapang berperan dalam menjaga keseimbangan ekosistem di perairan. Proses dekomposisi yang sangat kompleks dan rumit di laut membutuhkan peranan mikroorganisme, salah satunya adalah kapang. Kapang dapat membantu proses degradasi serasah dan batang mangrove karena kapang menghasilkan selulase (Anindyawati, 2010). Kapang berperan dalam melakukan penguraian lignin dan sellulosa (Kunarso, 1988). Selain itu, kapang juga hidup berasosiasi dengan organisme laut.

Sebagai mikroorganisme, proses identifikasi kapang secara morfologi sudah dianggap tidak terlalu efektif karena organisme ini bersifat cryptic karena sangat susah untuk membedakan antar spesies jika hanya menggunakan pendekatan morfologi (Sibero et al., 2018). Salah satu cara untuk meningkatkan keakuratan identifikasi adalah menggunakan pendekatan DNA barcoding. Penelitian ini dilakukan dengan tujuan mengidentifikasi dua kapang asosiasi spons asal ekosistem mangrove di Karimunjawa yang menjadi koleksi Sibero Project, Laboratory of Natural Product, Undip.

\section{MATERI DAN METODE}

Penelitian ini dilaksanakan di laboratorium Tropical Marine Biotechnology Fakultas Perikanan dan IImu Kelautan Universitas Diponegoro pada bulan Mei-Juni 2019. Pengolahan data serta analisa sampel dari hasil penelitian dilaksanakan pada Juni-Juli 2019.

\section{Peremajaan Isolat}

Stok kapang yang tersimpan pada gliserol dilakukan peremajaan pada cawan petri dengan media Potato Dextrose Agar (PDA) kemudian dilakukan inkubasi selama 7 × 24 jam (Gobalakrishnan \& Bhuvaneswari, 2019).

\section{Identifikasi Makroskopik dan Mikroskopik}

Kapang berfilamen diidentifikasi berdasarkan karakteristik makroskopis (kolonial) dan mikroskopisnya. Deskripsi kolonial termasuk karakteristik koloni seperti warna , tekstur, margin, ketinggian dan karakteristik hifa udara. Teknik slide culture dari Sibero et al. (2017) digunakan untuk pemeriksaan mikroskopis isolat kapang yang mencakup morfologi spora, warna, bentuk, ornamen atau tekstur dinding, ukuran, pembentukan konidia dan karakteristik terkait lainnya seperti pola phialide dan konidiasi. Deskripsi kapang di MycoBank (www.mycobank.com) digunakan sebagai panduan untuk identifikasi lebih lanjut dari isolat kapang.

\section{Ekstraksi DNA}

Metode chelex dimulai dengan mengisolasi DNA dengan metode saponin (Sibero et al. 2018). Miselia kapang diambil dan dimaukkan ke dalam microtube steril dan ditambahkan $1 \mathrm{~mL}$ saponin dan $100 \mu \mathrm{L}{ }_{d d} \mathrm{H}_{2} \mathrm{O}$ dan PBS, kemudian disimpan pada suhu $4{ }^{\circ} \mathrm{C}$ selama 24 jam.

Sampel microtube dicuci dengan cara disentrifugasi pada kecepatan 12.000 r.p.m. selama 10 menit, selanjutnya supernatannya dibuang dan ditambahkan ${ }_{d d} \mathrm{H}_{2} \mathrm{O}$ steril yang baru kemudian dicampur menggunakan vortex. Proses ini dilakukan sebanyak 2-3 kali dengan tujuan menghilangkan residu saponin. Pelet yang diperoleh dari hasil pencucian selanjutnya ditambahkan $100 \mu \mathrm{L}$ Chelex $10020 \%$ kemudian dipanaskan menggunakan heating block pada suhu $85^{\circ} \mathrm{C}$ selama 5 menit kemudian dicampur lagi menggunakan vortex lalu disentrifugasi kembali selama 5 menit. Sampel kembali dipanaskan lagi dengan suhu dan waktu yang sama dan disentrifugasi. 


\section{Amplifikasi DNA}

DNA kapang yang telah diisolasi selanjutnya diamplifikasi secara in vitro menggunakan polymerase chain reaction (PCR) (Sibero et al., 2018). Campuran PCR yang digunakan terdiri atas $12.5 \mu \mathrm{L}$ PCR mix master, $1 \mu \mathrm{L}$ primer forward (ITS1), $1 \mu \mathrm{L}$ primer reverse (ITS4), $1 \mu \mathrm{L}$ DNA kapang dan $9.5 \mu \mathrm{L} d_{d d} \mathrm{H}_{2} \mathrm{O}$ steril sehingga volume maksimal PCR tube adalah $25 \mu \mathrm{L}$. Protokol kondisi PCR untuk amplifikasi DNA akan sebanyak 30 kali siklus, yang terdiri atas: denaturasi DNA: $95^{\circ} \mathrm{C}$, selama 1 menit; annealing : suhu optimasi, selama 1 menit; ekstensi : $72^{\circ} \mathrm{C}$, selama 1 menit

\section{Pengecekan Kualitas Produk PCR}

Pengecekan kualitas produk PCR dilakukan menggunakan elektroforesis dengan buffer Tris base, asam asetat dan EDTA (TAE) 1X. Agarose direndam di dalam larutan pewarna ethidium bromide (Etbr) selama 30 menit. Agarose selanjutnya dimasukkan ke dalam gel documentation untuk disinari dengan lampu UV. Sampel dengan band DNA selanjutnya dikirim untuk disekuensing (Sibero et al., 2018). Tahapan sekuensing dilakukan oleh $1^{\text {st }}$ Base Malaysia.

\section{Analisis Sekuens dan Pembuatan Pohon Filogenetik}

Sekuens yang diperoleh selanjutnya diolah menggunakan software MEGA X. Untuk mengetahui spesies kapang maka sekuens yang diterima dari $1^{\text {st }}$ Base Malaysia dicocokkan pada pangkalan data di GenBank menggunakan Basic Local Alignment Search Tool (BLAST) yang terdapat di https://blast.ncbi.nlm.nih.gov/Blast.cgi.

Pohon filogenetik dilakukan dengan cara mensejajarkan seluruh sekuens dan sekuens pembandingnya. Analisis algortima dilakukan menggunakan metode Neighbor Joining (NJ) kemudian pengujian dilakukan dengan nilai bootstrap 10000 kali.

\section{HASIL DAN PEMBAHASAN}

Sebelum adanya penemuan teknik DNA barcoding, identifikasi kapang dilakukan menggunakan pengamatan makroskopis koloni dan mikroskopis dengan mikroskop. Penelitian ini menggabungkan pendekatan identifikais morfologi dan DNA barcoding untuk memberikan hasil yang lebih akurat. Tabel 1-2 dan Gambar 1-2 menunjukkan hasil karakterisasi makro dan mikroskopsi kedua isolat kapang. Hasil karakterisasi morfologi yang mencakup identifikasi makroskopik dan mikroskopik menunjukkan bahwa kapang MKMS 2.1 ketika diamati dibawah mikroskop memiliki konidiofor yang bercabang (branching), memiliki sekat (septa), dan tipe flask pada fialidnya dengan konidia yang tidak beronamen (smooth). Secara makroskopik, isolat mempunyai teksur miselia dengan tutupan serta konidia yang sangat banyak (powdery). Koloni isolat ini berwarna hijau dengan pola radial hijau dan kuning. Berdasarkan karakterisasi inilah, isolat ini diduga berasal dari genus Trichoderma.

Hal ini sesuai dengan penelitian Suanda (2019) yang menyatakan bahwa genus Trichoderma memiliki ciri ciri morfologis; tekstur powdery dengan warna koloni kuning-hijau, reverse color kuninghijau, tidak terdapat sclerotia dan exudates. Sedangkan pada penelitian Ghazanfar et al. (2018); Waghunde et al. (2016), menyatakan bahwa genus Trichoderma memiliki bentuk konidia smooth atau ellipsoidal, bentuk konidiofor yang bercabang, memiliki tipe hifa yang bersekat, dan bentuk fialid seperti flask. Genus Trichoderma adalah kapang berfilamen dalam fase aseksual teleomorph milik urutan Hypocreales divisi Ascomycota. Fungsi ekologis Trichoderma sebagai dekomposer residu di lingkungan. Beberapa spesies dari Trichoderma menghasilkan enzim selulase yang baik sehingga Trichoderma mempunyai peran penting dalam bidang boteknologi. Misalnya, beberapa spesies dari genus ini memiliki kemampuan antagonis untuk melawan kapang patogen. Strain Trichoderma yang memiliki kemampuan antagonis pada patogen tanaman dapat menjadi kandidat potensial untuk agen biokontrol (Kredics et al., 2003). Menurut Gultom (2008) mekanisme antagonis kapang Trichoderma seperti a) kompetisi nutrisi dalam jumlah terbatas tetapi tidak diperlukan oleh organisme/mikroorganisme pathogen, b) antibiosis sebagai produk metabolit sekunder yang dihasilkan ketika merasa terancam, dan c) predasi, hiperparasitisme, dan mikroparasitisme. Genus Trichoderma termasuk kapang cosmopolitan karena hampir ditemukan di seluruh wilayah. Hal ini 
dapat dikarenakan spora kapang genus Trichoderma yang dapat menyebar melalui udara dan kolom air, sehingga dapat sampai keperairan dan ditangkap oleh spons.

Secara makroskopik, isolat PKMS 2.2 mempunyai teksur miselia powdery. Warna koloni adalah putih. Warna reverse mayoritas adalah putih menuju kuning kecokelatan. Isolat ini ketika diamati dibawah mikroskop semuanya memiliki tipe konidiofor branching, dengan tipe konidia yaitu mikro konidia, tipe hifa yang bersekat dan fialid bertipe monofialid. Dari pengamatan tersebut, isolat ini berasal dari genus Fusarium (Hafizi et al., 2013). Spesies Fusarium dapat menghasilkan tiga jenis spora yang disebut macroconidia, microconidia, dan chlamydospores. Macroconidia diproduksi di sporodochum (struktur khusus) diproduksi dalam struktur khusus yang disebut sporodochium. Microconidia diproduksi di aerial misselia. Microconidia dapat di produksi di kepala atau rantai tiruan pada fialid. Chlamydospores, yaitu spora berdinding tebal yang berisi lipid dan akan berfungsi untuk berpindah tempat ketika kondisi inang tidak cocok (Nelson et al., 1994).

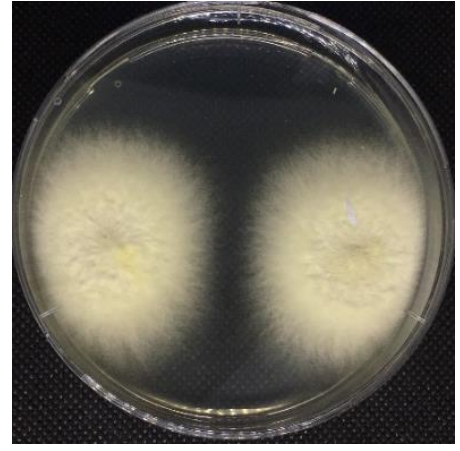

(a)

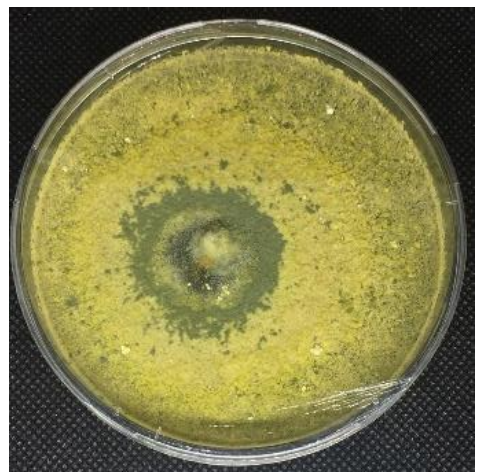

(c)

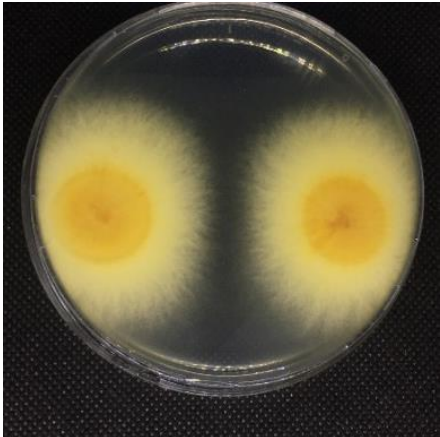

(b)

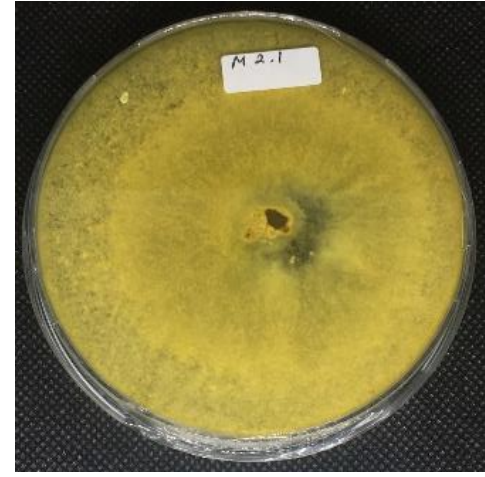

(d)

Gambar 1. Isolat Kapang PKMS 2.2. (a); tampak depan isolat, (b); tampak belakang isolat Isolat Kapang MKMS 2.1 (c); tampak depan isolat, (d); tampak belakang isolat Isolat

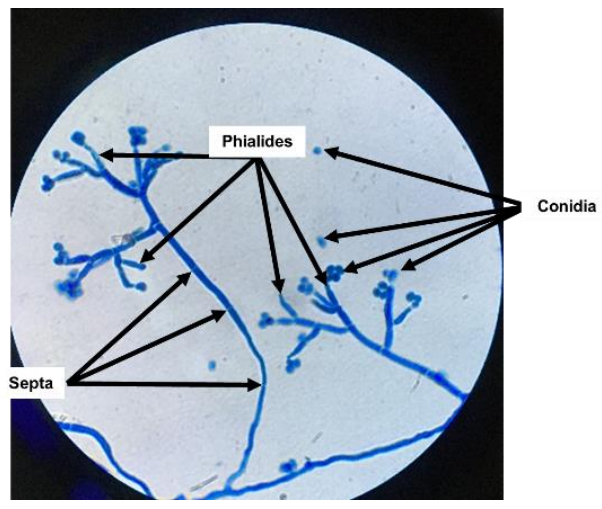

Gambar 2. Karakteristik mikroskopik konidiofor isolat MKMS 2.1 


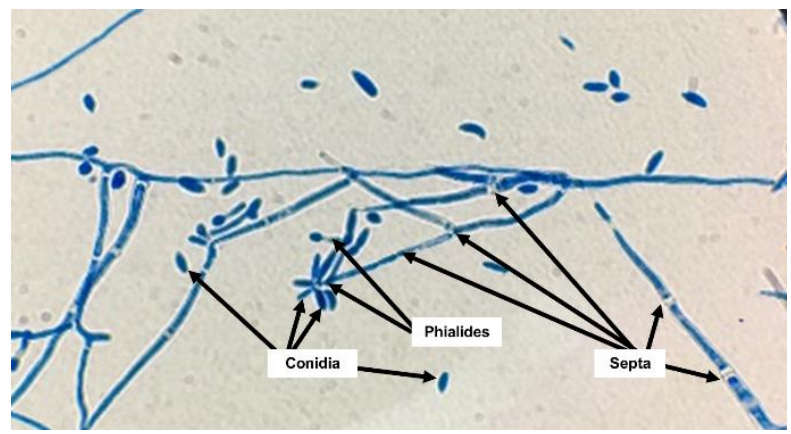

Gambar 3. Karakterisasi mikroskopik konidiofor isolat PKMS 2.2

Tabel 1. Karakterisasi Makroskopik

\begin{tabular}{rcccccc}
\hline \multirow{2}{*}{ Isolat } & \multicolumn{5}{c}{ Karakteristik Makroskopik } \\
\cline { 2 - 6 } & $\begin{array}{c}\text { Colony } \\
\text { color }\end{array}$ & $\begin{array}{c}\text { Colony } \\
\text { texture }\end{array}$ & Mycellium & Exudates & Reverse & Sclerotia \\
\hline MKMS 2.1 & White & Granular & Green & No & Green & No \\
PKMS 2.2 & White & Wolly & White & No & White & No \\
\hline
\end{tabular}

Tabel 2. Karakterisasi Mikroskopik

\begin{tabular}{lcccc}
\hline \multirow{2}{*}{ Isolat } & \multicolumn{4}{c}{ Karakteristik Mikroskopik } \\
\cline { 2 - 4 } & Conidiophore & Conidia & Phialides & Hyphae \\
\hline MKMS 2.1 & Branching & Ellipsoidal & Flask & Septum \\
PKMS 2.2 & Branching & Microconidia & Monofialid & Septum \\
\hline
\end{tabular}

DNA barcoding dilakukan setelah pengamatan morfologi untuk mengkonfirmasi dugaan awal genus kedua isolat. Hasil sekuens dipengaruhi oleh keberhasilan proses PCR sampai dengan elektroforesis. Keberhasilan amplifikasi ini dipengaruhi oleh banyak faktor, antara lain keberhasilan ekstraksi DNA, kemurnian DNA, komposisi larutan PCR, kondisi reaksi dan suhu yang digunakan saat proses annealing atau penempelan primer. Kualitas pita DNA untuk menentukan konsentrasi primer optimum dapat dipengaruhi oleh konsentrasi DNA template dan konsentrasi primer itu sendiri. Kualitas PCR dan spesifisitas tergantung pada konsentrasi primer optimal yaitu 0.1-2.0 $\mu \mathrm{M}$ (Loffert et al., 1999).

Optimasi suhu annealing dilakukan dengan menggunakan gradient annealing saat PCR. Suhu annealing yang optimal adalah $55^{\circ} \mathrm{C}$. Artinya, penempelan primer optimal pada suhu $55^{\circ} \mathrm{C}$ dan DNA dapat teramplifikasi. Hasil identifikasi berdasarkan persamaan BLAST homology didapatkan kesamaan isolat MKMS 2.1 dengan Trichoderma reesei (MT421898.1) sebesar 100\% dengan query cover $100 \%$. Hal ini menunjukkan bahwa kesamaan basa yang dimiliki isolat dengan Trichoderma ini sangat mirip sehingga dapat dikatakan bahwa isolat ini adalah spesies Trichoderma reesei. Sedangkan isolat PKMS 2.2 berdasarkan persamaan BLAST homology merupakan spesies Fusarium solani (MK961121.1) dengan prosentase query cover $100 \%$ dengan prosentasi identifikasi $99,82 \%$.

Konstruksi pohon filogenetik menggunakan Aureobasidium melanogenum sebagai outgroup (KP965486.1) (Gambar 4). PKMS 2.2 memiliki kesamaan dengan Fusarium solani dengan hasil bootstrap 95\% dimana artinya 95\% pembentukkan cabang pohon filogenetik akan membentuk cabang yang sama. Metode bootstrap merupakan analisis pengujian baik atau tidaknya set data model. Artinya, sebagai validitas terhadap penyusunan cabang untuk memprediksi tingkat resampled dalam membentuk cabang dan ranting pohon filogenetik. Jarak genetik pada pohon filogenetik menunjukan nilai sebesar 0.20 , dimana nilai ini menunjukkan adanya perbedaan 20 basa dalam setiap 100 basa tiap sekuensnya. Dalam konstruksi filogenetik menggunakan metode neighbor joining dan analisis bootstrap (10000 kali ulangan) dan menghasilkan nilai sebesar $90 \%$ yang berarti sekuens isolat ini berbeda nyata dengan outgrup karena memiliki urutan pasangan basa 
yang berbeda jauh (Dharmayanti, 2011). Konstruksi pohon filogenetik adalah hal terpenting untuk menentukan jarak evolusi pada spesies tertentu. Filogenetik dapat diartikan sebagai klasifikasi dari organisme secara taksonomi dan pusat dari evolusi biologi, dimana terdapat paradigma keseluruhan bagaimana organisme berkembang dan hidup di alam. Analisis filogenetik ini dapat dilihat berdasarkan gap yang terbentuk setelah proses multiple alignment. Gap yang terbentuk dapat menunjukan delusi atau inersi dari satu atau lebih sekuens selama evolusi. Hal ini dapat diartikan pula sebagai mutasi genetik dalam sekuens. Metode neighbor joining adalah metode akurat untuk pohon yang memiliki cabang yang pendek. Cabang panjang yang terbentuk bertendensi menurunkan kepercayaan dari prediksi.

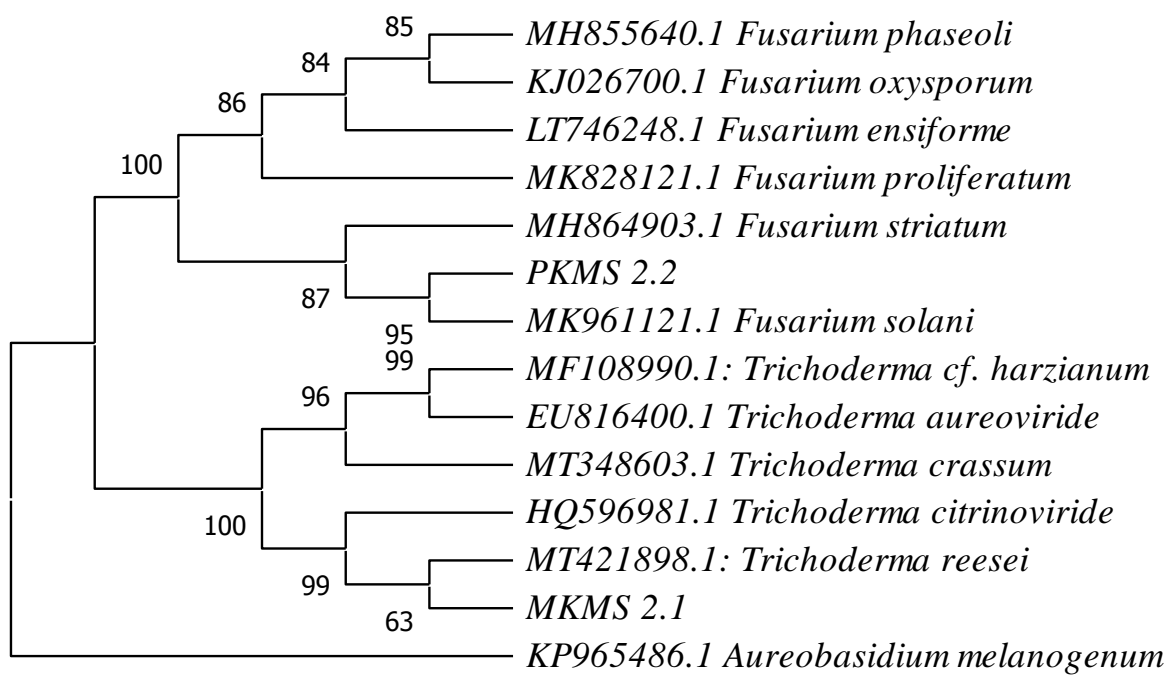

Gambar 4. Pohon filogenetik dua isolat kapang asosiasi spons asal ekosistem mangrove (Rekonstruksi dilakukan menggunakan urutan nukleotida pada region parsial 18S, ITS1, 5.8S, ITS 2 dan parsial 26S rDNA)

\section{KESIMPULAN}

Identifikasi molekuler menunjukkan bahwa isolat MKMS 2.1 adalah Trichoderma reesei (MT421898.1) yang mempunyai persamaan BLAST homology sebesar $100 \%$ dengan query cover $100 \%$ dan isolat PKMS 2.2. merupakan Fusarium solani (MK961121.1) dengan persamaan BLAST homology sebesar $99,82 \%$ dan query cover sebesar $100 \%$.

\section{DAFTAR PUSTAKA}

[FAO] Food and Agriculture Organization of the United Nation. 2017. Sponge and their role in the marine environment.

Anindyawati, T. 2010. Potensi selulase dalam mendegradasi lignoselulosa limbah pertanian untuk pupuk organik. Jurnal Selulosa, 45(02):70-77

Bell, J.J. 2008. The functional roles of marine sponges. Estuarine, Coastal, and Shelf Science 79: 341-353. Doi: 10.1016/j.ecss.2008.05.002.

Burns, E., Ifrach, I., Carmeli, S., Pawlik, J.R. \& Ilan, M. 2003. Comparison of anti-predatory defenses of Red Sea and Caribbean sponges. I. Chemical defense. Marine Ecology Progress Series, 252:105-114.

Dharmayanti, N.L.P.I. 2011. Filogenetika molekuler: metode taksonomi organisme berdasarkan sejarah evolusi. Wartazoa, 21(1):1-10.

Ghazanfar, M.U., Raza, M., Raza, W., \& Qamar, M.I. 2018. Trichoderma as potential biocontrol 
agent, its exploitation in agriculture: a review. Plant Protection, 2(3):109-135

Gultom, J.M., 2008. Pengaruh Pemberian Beberapa Jamur Antagonis dengan Berbagai Tingkat Konsentrasi Untuk Menekan Perkembangan Jamur Phytium sp Penyebab Rebah Kecambah pada Tanaman Tembakau (Nicotiana tabaccum L.) http://repository.usu.ac.id.pdf. Diakses 20 Mei 2020

Kredics, L., Antal, Z., Dóczi, I., Manczinger, L., Kevei, F. \& Nagy, E.. 2003. Clinical Importance Of The Genus Trichoderma. Acta microbiologica et immunologica Hungarica, 50(2-3):105-117.

Kunarso, D.H. 1988. The importance of heterotrophic bacteria in marine ecosystem. Oseana

Loffert, D., Karger, S., Twieling, G., Ulber, V. \& Kang, J. 1999. Optimization of multiplex PCR. Qiagen news. 2:5-8.

Miranti, A.K., Rukmi, M.I. \& Suprihadi, A. 2015. Diversitas Kapang Serasah Daun Talok (Muntingia calabura L.) Di Kawasan Desa Sukolilo Barat, Kecamatan Labang, Kabupaten Bangkalan, Madur. Bioma: Berkala IImiah Biologi, 16(2):58-64.

Richards, T.A., Jones, M.D.M., Leonard, G. \& Bass, D. 2012. Marine fungi: their ecology and molecular diversity. Annual Reviews of Marine Science, 4:495-522.

Sibero, M.T., Tarman, K., Radjasa, O.K., Sabdono, A., Trianto, A. \& Bachtiarini, T.U. 2018. Produksi Pigmen dan Identifikasi Kapang Penghasilnya Menggunakan Pendekatan DNA Barcoding. Jurnal Pengolahan Hasil Perikanan Indonesia, 21(1):99-108.

Sibero, M. T., Sabdaningsih, A., Cristianawati, O., Nuryadi, H., Radjasa, O. K., Sabdono, A., \& Trianto, A. 2017. Isolation, identification, and screening antibacterial activity from marine sponge associated-fungi against multidrug-resistant (MDR) Escherichia coli. IOP Conf. Series: Earth and Environmental Science, 55:012028.

Suanda, I.W. 2019. Karakterisasi Morfologis Trichoderma Sp. Isolat Jb Dan Daya Hambatnya Terhadap Jamur Fusarium Sp. Penyebab Penyakit Layu Dan Jamur Akar Putih Pada Beberapa Tanaman. Jurnal Widya Biologi, 10(02):99-112.

Thoms, C., Schupp, P.J., Custódio, M.R., Lôbo-Hajdu, G., Hajdu, E. \& Muricy, G. 2007. Chemical defense strategies in sponges: a review. Porifera research: biodiversity, Innovation and sustainability, 28:627-637.

Waghunde, R.R., Shelake, R.M., \& Sabalpara, A.N. 2016. Trichoderma: A significant fungus for agriculture and environment. African Journal of Agricultural Research, 11(22):1952-1965. 